\title{
Identification of a high catalytic efficiency beta-amylase from Bacillus aryabhattai GEL-09
}

Xinyi Zhang ${ }^{1}$, Xuguo Duan ${ }^{1}{ }^{*}$, Shuyue Luan ${ }^{1}$, Qiuyu Zhu ${ }^{1}$, Huixing $\mathrm{Li}^{2}$, Yongcan $\mathrm{Jin}^{1}$

1 College of Light Industry and Food Engineering, Nanjing Forestry University, Nanjing, China. 2 Henan Key Laboratory of Industrial Microbial Resources and Fermentation Technology, Nanyang, China. *Corresponding author. E-mail: xgduan@njfu.edu.cn (Xuguo Duan)

\section{Abstract}

$\beta$-amylase (EC 3.2.1.2), catalyzing the hydrolysis of the second $\alpha-1,4$ glycosidic bond from nonreducing end of amylose or amylopectin, is a exo-type enzyme that plays a significant role in the production of maltose syrup. In this study, a novel $\beta$-amylase (amyB) was characterized from Bacillus aryabhattai GEL-09. It showed that the amyB encoding gene was composed of $1542 \mathrm{bp}$, which encodes a protein containing 514 amino acid residues. The amino acid sequence alignment revealed that the $\beta$ amylase from Bacillus aryabhattai shared the highest identity of $74 \%$ with that from Bacillus cereus. The amyB was over-expressed in $E$. coli BL21(DE3) and the recombinant enzyme was purified to homogeneity. The molecular weight of the recombinant $\beta$-amylase was estimated to be about $57.6 \mathrm{kDa}$ by SDS-PAGE The recombinant $\beta$-amylase has maximum activity at $50^{\circ} \mathrm{C}$, and $\mathrm{pH} 6.0$, and it maintained 53,72 and $94 \%$ relative activity at 30,40 and $60^{\circ} \mathrm{C}$, respectively. In the presence of $\mathrm{Co}^{2+}$, the activity of the recombinase was enhanced and was inhibited by EDTA, and other metal ions had little effect on the activation or inhibition of the enzyme. The kinetic analysis showed that when the soluble starch was used as the substrate, the michaelis constant $\left(K_{\mathrm{m}}\right)$ was $9.9 \mathrm{mg} \mathrm{mL}^{-1}$, the catalytic constant $\left(K_{\text {cat }}\right)$ was $116961.1 \mathrm{~s}^{-1}$, and the $K_{\text {cal }} / K_{\mathrm{m}}$ was $11733.7 \mathrm{~mL} \mathrm{~s}^{-1} \mathrm{mg}^{-1}$. The enzyme showed the highest specificity for soluble starch. followed by corn starch. Then the recombinant $\beta$-amylase was used to transform soluble starch $(10 \%)$ into maltose, the yield of maltose reached $55.14 \%(\mathrm{w} / \mathrm{w})$ after $24 \mathrm{~h}$. The $\beta$-amylase identified in this study has potential applications in the starch sugar industry.

Results

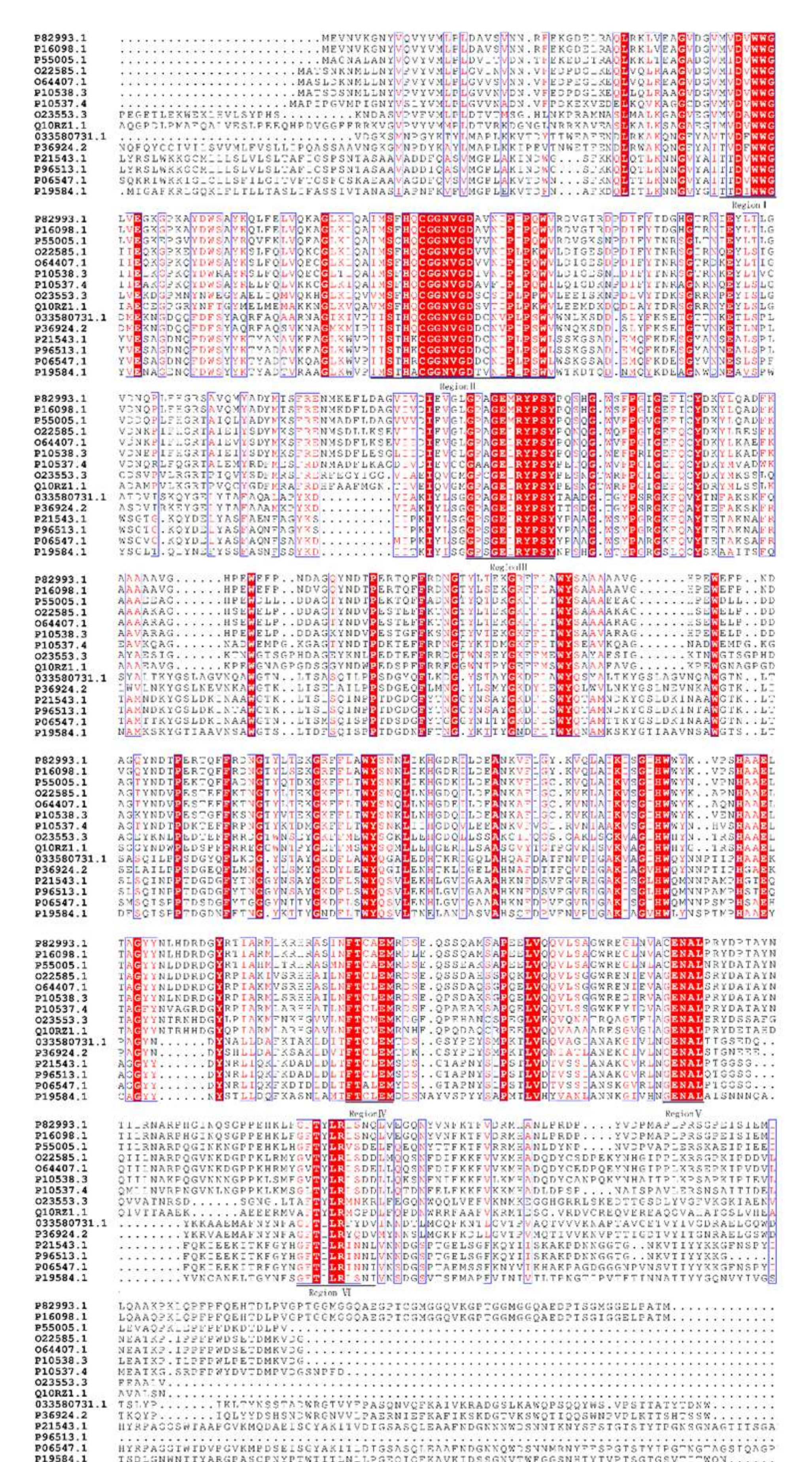

Fig.1 Multiple sequence alignment of $\beta$ amylase protein sequences indicating highly conserved residues highlighted by red box Accession numbers of the $\beta$-amylases are as spontaneum(P82993.1), Hordeum vulgar P16098.1), Zea mavs (P55005.1) Medicago sativa (O22585.1), Vigna unguiculata (O64407.1), Glycine mat (P10538.3), Ipomoea batatas (P10537.4) Arabidopsis thaliana (O23553.3), Oryza sativa Japonica Group (Q10RZ1.1), Bacillus aryahhattai (033580731.1), Bacillus cerens (P21543.1), Bacillus firmus (P96513.1), Bacillus circulans (P06547.1) (B) thermosulfurigenes (P19584.1). The six conserved regions (I, II, III, IV, V, VI) are shown by underline. follows: Hordeum vulgare subsp. (P36924.2), Paenibacillus polymyxa
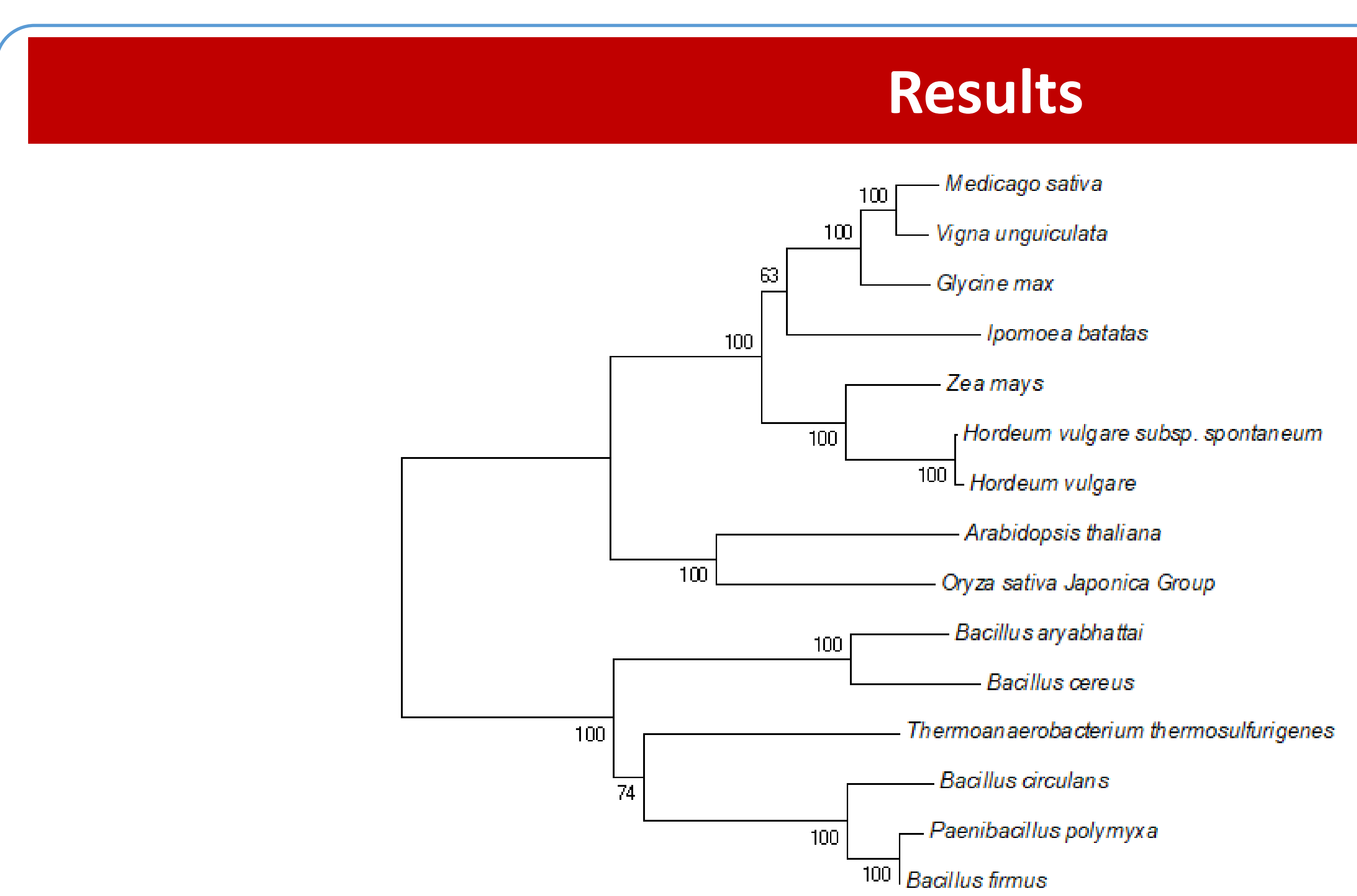

20

heen constructed by NJ method based on $\beta$-amylase protein sequences from different plants and microorganisms. The evolutionary distance and branch length have been shown in the figure.

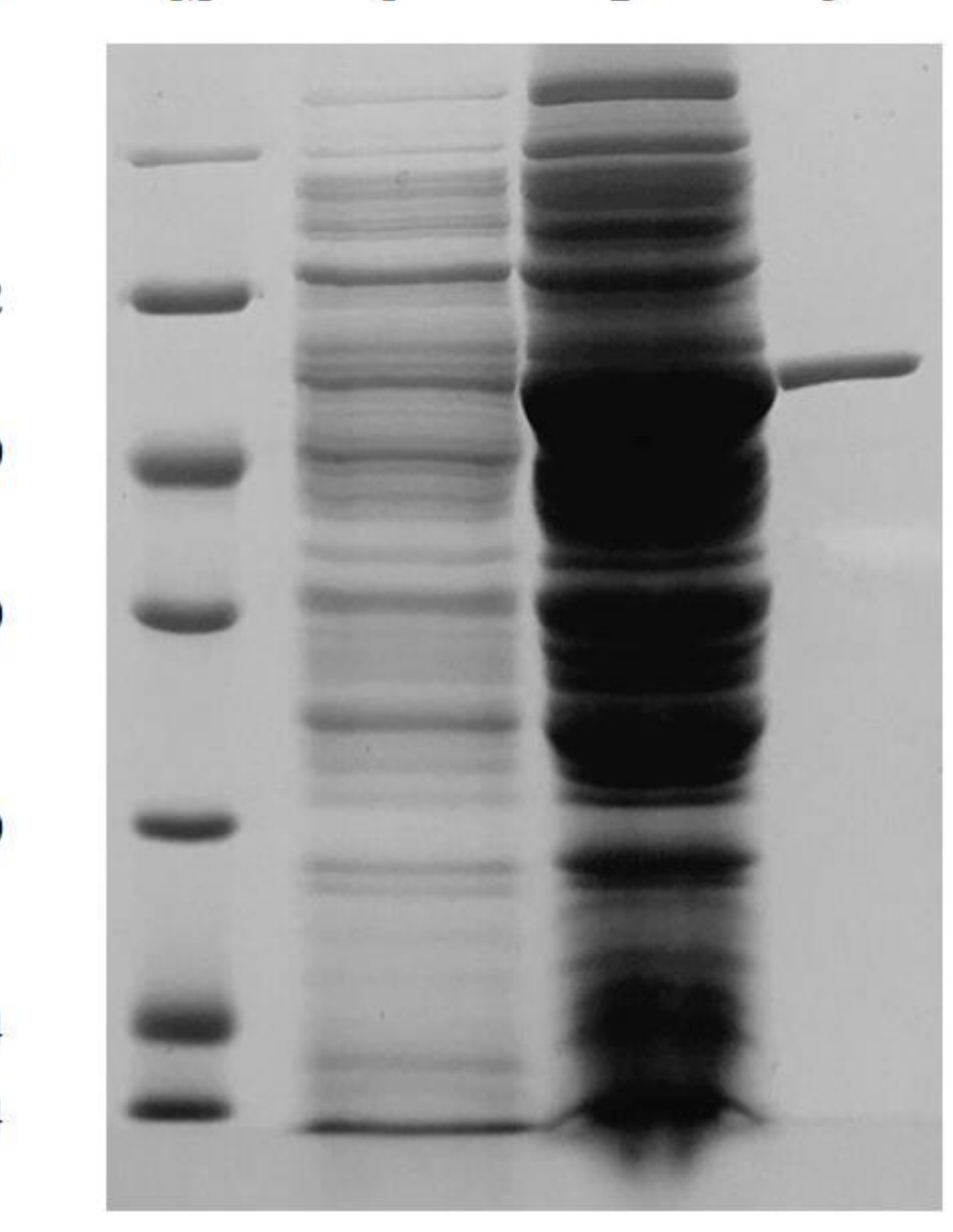

Fig. 3 SDS-PAGE analysis of $\beta$-amylase. Lane $M$, protein size standard; lane1, Fermentation supernatan of E. coli lane3,Purification on DEAE Ion exchange column

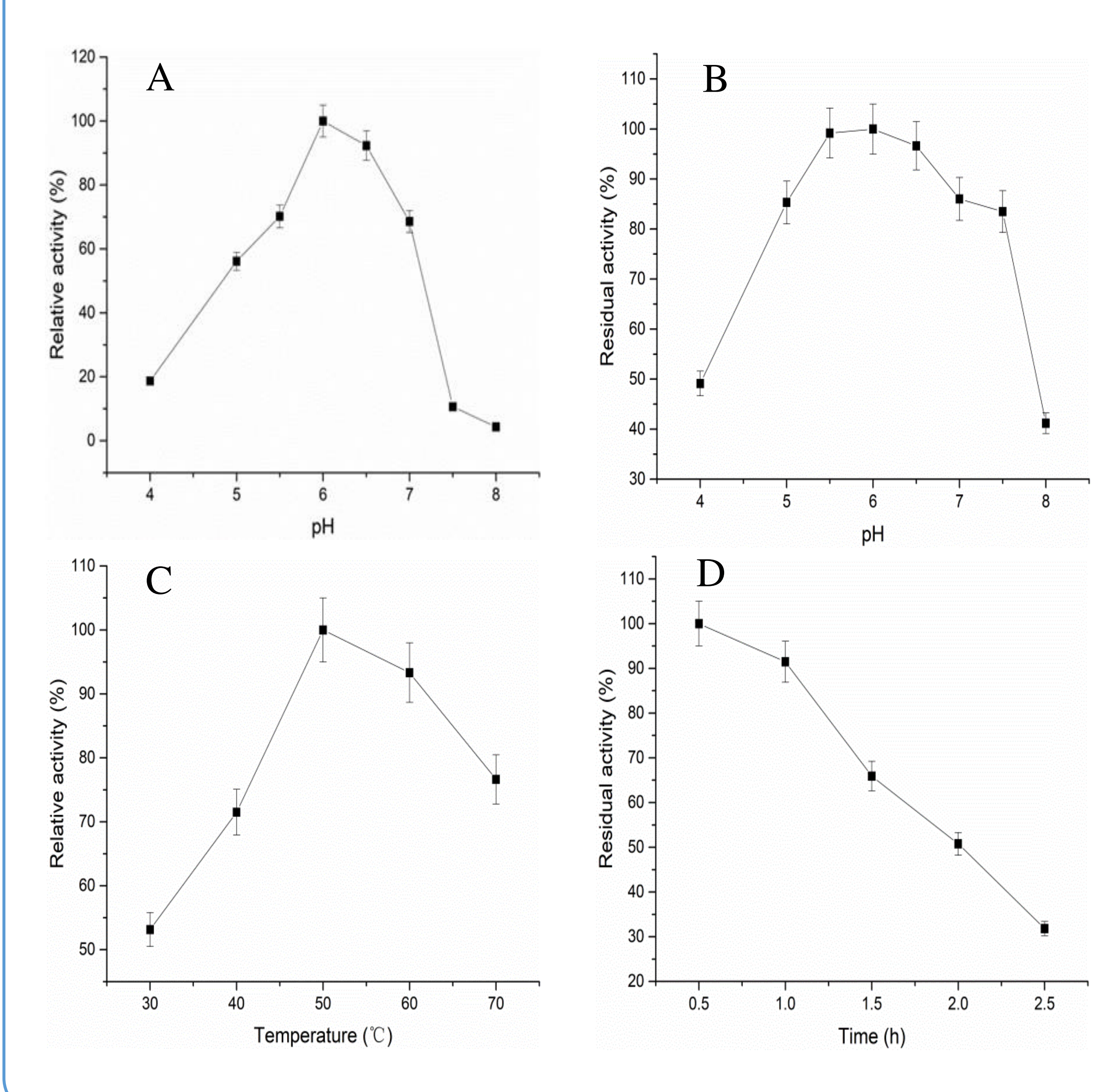

ig. 4 The effect of temperature and p effect of $\mathrm{pH}$ on the activity of $\beta$ in different buffers of $0.2 \mathrm{M} \mathrm{Na}_{2} \mathrm{HPO}^{-}$ Citric acid buffer (pH 4.0-8.0) at $50^{\circ} \mathrm{C}$. (b) The effect of $\mathrm{pH}$ on the stability of $\beta$-amylase. The $\mathrm{pH}$ stability was h in the range of $\mathrm{pH} 40-8 \mathrm{O}$ a $4^{\circ} \mathrm{C}$ The enzyme activity of the preincubation was determined to be $100 \%$ under optimal conditions. (c) The effect of temperature on the carried out in a $0.2 \mathrm{M} \mathrm{Na}_{2} \mathrm{HPO}_{4}$-Citric acid buffer at $\mathrm{pH} 6.0$ at different temperatures from 30 to $70{ }^{\circ} \mathrm{C}$ for 10 min. (d) The thermal stability test of carried out at $50^{\circ} \quad C$ and $p H 6$ lase was the $\beta$-amylase hydrolase activity was measured periodically.

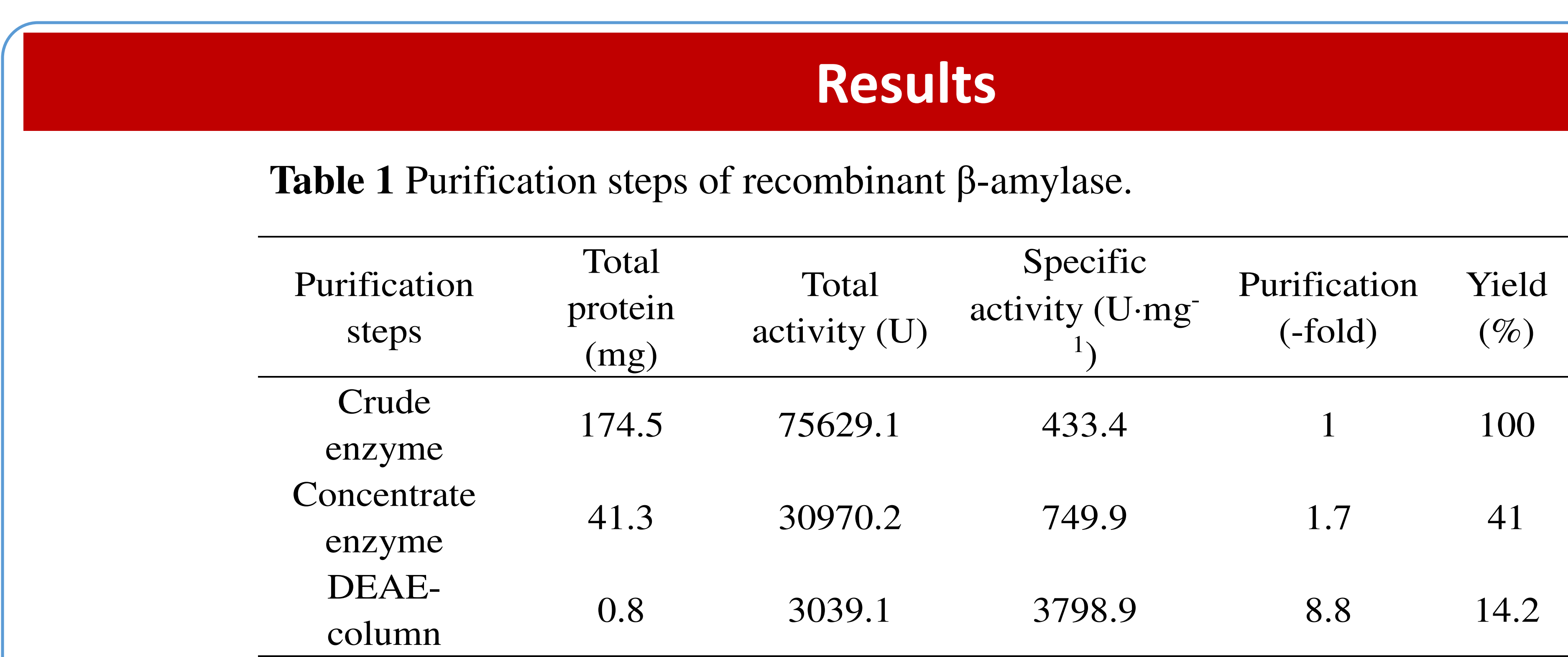

table 2 Effects of metal ions and other reagents on the activity of recombinant $\beta$-amylase Modulator - Concentration

\begin{tabular}{lll}
\hline Cations & & \\
$\mathrm{Cu}^{+2}$ & $1 \mathrm{mM}$ & 93.91 \\
$\mathrm{Zn}^{2+}$ & $1 \mathrm{mM}$ & 98.78 \\
$\mathrm{Ca}^{2+}$ & $1 \mathrm{mM}$ & 88.42 \\
$\mathrm{Mn}^{2+}$ & $1 \mathrm{mM}$ & 99.39 \\
$\mathrm{Co}^{2+}$ & $1 \mathrm{mM}$ & 115.11 \\
$\mathrm{Mg}^{2+}$ & $1 \mathrm{mM}$ & 95.00 \\
$\mathrm{Fe}^{2+}$ & $1 \mathrm{mM}$ & 94.52 \\
$\mathrm{Cu}^{+2}$ & $5 \mathrm{mM}$ & 38.61 \\
$\mathrm{Zn}^{2+}$ & $5 \mathrm{mM}$ & 115.20 \\
$\mathrm{Ca}^{2+}$ & $5 \mathrm{mM}$ & 84.65 \\
$\mathrm{Mn}^{2+}$ & $5 \mathrm{mM}$ & 94.13 \\
$\mathrm{Co}^{2+}$ & $5 \mathrm{mM}$ & 114.44 \\
$\mathrm{Mg}^{2+}$ & $5 \mathrm{mM}$ & 85.56 \\
$\mathrm{Fe}^{2+}$ & $5 \mathrm{mM}$ & 96.24 \\
Chelating agent & & \\
EDTA & $1 \mathrm{mM}$ & 75.02 \\
EDTA & $5 \mathrm{mM}$ & 62.84 \\
\hline
\end{tabular}

Table 3 The kinetic paraments of recombinant $\beta$-amylase

\begin{tabular}{ll}
\hline Kinetic paraments & Data \\
\hline$V_{\max }\left(\mathrm{U} \cdot \mathrm{mg}^{-1}\right)$ & $6660.0 \pm 577.1$ \\
$K_{\text {cat }}\left(\mathrm{s}^{-1}\right)$ & $116961.1 \pm 10134.9$ \\
$K_{\mathrm{m}}\left(\mathrm{mg}^{\mathrm{m}} \cdot \mathrm{mL}^{-1}\right)$ & $9.9 \pm 2.1$ \\
$K_{\text {cal }} / K_{\mathrm{m}}\left(\mathrm{mL}^{-1} \cdot \mathrm{mg}^{-1}\right)$ & $11733.7 \pm 1016.7$ \\
\hline
\end{tabular}

In this stady, the p-anylase gene amyBary from $B$. anybhatai was cloned and solubly expressed in $E$. coli. Recombinant $\beta$-amylase contained six conserved regions that were typical of all $\beta$-amylase. HPLC analysis demonstrated that the yield of maltose was $55.14 \%$ after $24 \mathrm{~h}$. These results demonstrated that the $\beta$-amylase identified in this study has potential applications in the starch sugar industry.

\section{Acknowledgements}

This work was supported by a grant from Nanjing Forestry University [grant number GXL2018010], Henan Key Laboratory of Industrial Microbial Resources and Fermentation Technology [grant number IMRFT20180102], the National Natural Science Foundation of China [grant number 31401636], the Priority Academic Program Development of Jiangsu Higher Education Institutions (PAPD). 